\title{
TEACHERS' INTENTION TO CONTINUE USING VIRTUAL LEARNING ENVIRONMENT (VLE): MALAYSIAN CONTEXT
}

\author{
Hapini Awang ${ }^{1}$ (D) Zahurin Mat Aji ${ }^{1}$ (D) Mohd Faiz Mohd Yaakob ${ }^{1}$ (D), \\ Wan Rozaini Sheik Osman' ${ }^{1}$, Amirul Mukminin ${ }^{2}$ iD, Akhmad Habibi ${ }^{2}$ iD \\ ${ }^{1}$ Universiti Utara Malaysia (Malaysia) \\ ${ }^{2}$ Jambi University (Indonesia) \\ bapiniawang@gmail.com,zahurin@uum.edu.my,mohd.faiz@uum.edu.my,wanrozaini57@gmail.com, \\ amirmuk06@gmail.com,akhmad.habibi@unja.ac.id
}

Received May 2018

Accepted July 2018

\section{Abstract}

Malaysian teachers have been using Virtual Learning Environment (VLE) technology in their instructional activities since it was introduced by the Ministry of Education in 2012. This study aimed to measure Malaysian teachers' level of intention to continue using VLE technology and investigate factors influencing teachers' decision to keep using VLE into teaching and learning process. Implementing sequential explanatory design, we addressed 850 questionnaires and conducted interview with 10 teachers. After data screening procedure, only 643 questionnaires were usable and measurable in the data analysis. Fifty-one teachers answered the open ended question included in the questionnaire. We further asked questions adapted from the data analysis of the questionnaires to ten teachers. The results of the study informed that the overall mean score of teachers' intention to continue using VLE is 4.21. This mean score indicated that the intention to continue using VLE technology among the Malaysian teachers is at the moderate level. Despite this, the percentage of the teachers with high intention to use VLE whenever they have access is higher than those with the low intention. Qualitatively, accessibility factor was the main factor experienced by the participants of this study reducing the VLE integration into teaching. Further investigation is necessary to study the factors and suitable planning and policy that contribute to the intention to continue using VLE among Malaysian teachers.

Keywords - Intention to use, Frog VLE, E-learning, Malaysian teachers.

\section{To cite this article:}

Awang, H., Aji, Z.M., Yaakob, M.F.M., Osman, W.R.S., Mukminin, A., \& Habibi, A. (2018). Teachers’ intention to continue using Virtual Learning Environment (VLE): Malaysian context. Journal of Technology and Science Education, 8(4), 439-452. https:/ / doi.org/10.3926/jotse.463

\section{Introduction}

Virtual Learning Environment (VLE) is defined as computer-based environments that are relatively open systems, allowing interactions with other participants and access to a wide range of resources (Britain \& Liber, 2004; Wilson, 1996). VLE, usually applied in schools or higher institutions has been known as an effective medium to enhance the quality of teaching and learning. Furthermore, the development of 
sophisticated inventions of ICT tools including VLE has shifted the nature of teaching and learning (Barker \& Gossman, 2013; Mosquera, 2017). Nowadays, the new kind of pedagogy strategies such as blended learning and on-line learning has become common with the aid of VLE. In this sense, it has changed the traditional nature of learning approach by promoting virtual learning model beyond the boundaries of time and space, by facilitating a means for learning experience management, and providing teachers and students with technology-integrated environment (Sneha \& Nagaraja, 2013). The introduction of VLE into education has produced positive impacts to teachers, students, and parents by promoting the dynamicity in learning especially in term of defying the barriers of time and location (Nor-Fadzleen \& Halina, 2013; Uzunboylu, Bicen \& Cavus, 2011). It also enables users to mutually communicate to each other in a synchronous and asynchronous way (Halonen, Thomander \& Laukkanen, 2010.

The implementation VLE technology in Malaysia, known as Frog VLE was a part of educational information systems expansion initiated by Ministry of Education, Malaysia (MOE) through 1BestariNet project to improve the previous version of School Net service (MOE, 2014). MOE has allocated approximately RM1.475 Billion for Frog VLE implementation (MOE, 2014). MOE has spent RM250.50 million for VLE license and another RM262.81 million for maintenance during two years and half of contract until 2014 (MOF, Ministry of Finance, 2014). However, despite this large-scale investment, the recent audit report indicates the low usage of ICT $(80 \%$ of the teachers use less than an hour in a week) including Frog VLE (19.5\% to 33.5\%). Concerning teachers' usage, the analysis for 1st to 31st March 2014 has recorded only $0.57 \%$ to $4.69 \%$ of Frog VLE utilization for that particular time (MOF, 2014; Xchanging, 2014). The low utilization of VLE is possibly an early symptom of failure also due to the rejection by its users, primarily the teachers as the level of usage is recognized as the main force that will determine the success of its implementation

Furthermore, most researchers agreed that the degree of utilization is a crucial part of information system (IS) success (e.g. Cheok \& Wong, 2016); DeLone \& McLean, 2003; Eom, Ashill, Arbaugh \& Stapleton, 2012; Goldin \& Katz, 2018; Raman \& Rathakrishnan, 2018; Zhou, 2013). Indeed, the low utilization of Frog VLE is closely associated to the issue of continuous usage; few studies have been provided findings about the continuation of the VLE use in education. Therefore, this current study using survey and in-depth interview was conducted to measure Malaysian teachers' level of intention to continue using VLE technology as well as investigate the factors influencing teachers' decision to keep using VLE into teaching and learning process VLE integration into teaching.

\section{Literature Review}

\subsection{ICT for Education}

ICT in education refers to the process of teaching and learning with the aid of certain medium and technology (Habibi, Mukminin, Riyanto, Prasohjo, Sulistiyo, Sofwan et al., 2018; Peeraer \& Van-Petegem, 2011; Vanderlinde, Aesaert \& Van-Braak, 2014). The level of success for ICT integration in education differs in each country around the world. Developed countries such as Finland, Singapore, South Korea, United Kingdom, and the United States have proved that ICT use in education is effective and regularly implemented by the teachers (Dimelis \& Papaioannou, 2010; Hu, Gong, Lai \& Leung, 2018; Niebel, 2018; Owen, Palekahelu, Sumakul, Sekiyono \& White, 2017). On the contrary, other countries especially developing countries e.g. Argentina, Brazil, Indonesia, and Malaysia are still in the beginning stage of ICT integration, without any clear positive sign of revenue for the investment (Bhuasiri, Xaymoungkhoun, Zo, Rho \& Ciganek, 2012; Karunaratne, Peiris \& Hansson, 2018; Kozma \& Vota, 2014; Lubin \& Lubin, 2018; Prasojo, Habibi, Mukminin, Muhaimin, Ikhsan, Taridi et al., 2017).

Arose from a long period of colonization, Malaysia is now considered as one of the fast growing countries in Asia which success lies on the high priority given by the government to the educational sector (Wirawani \& Rosnani, 2013). Statistics produced indicated that there were 7,763 primaries and 2,397 secondary schools, operated by 424,443 professional teachers across the nation (MOE, 2015a, 2015b). In line with the utilization of ICT in education, high priority in terms of policies has been given to the 
integration of ICT since 1997-2005, with the introduction of smart school project, education development plan for 2006-2010 (MOE, 2006), Malaysian education development plan 2013-2025 (Wirawani \& Rosnani, 2013). One of integral strategies in the latest policy is 1 BestariNet aiming to be the platform for data integration as well as equipping the teachers with sufficient data management training (MOE, 2012a). The installation of Frog appliance is to equip the teachers with latest gadgets such as smartphones and tablets with high speed connection (MOE, 2015a, 2015b). This high-speed network, along with high-end infrastructures in every school in Malaysia should promote the VLE implementation and thus assist teachers in coping with educational challenges in the digital age.

\subsection{VLE Integration and its Hindrance}

VLE sometimes referred as E-Learning or Learning Management System is a type of E-Learning system that is implemented in various educational settings such as universities, training centers and schools to systematically support the online learning and administrations (Mueller \& Strohmeier, 2011). It is commonly recognized as an internet-based platform that support various educational activities including online courses, quizzes, and tutorials (Abdelhag \& Osman, 2014) that have positive influence on educational technology administration, teaching and learning flexibility and digital proficiency amongst the stakeholders. VLE usually uses Web 2.0 technology that can support distance learning as well as blended learning (Abdelhag \& Osman, 2014; Raman \& Rathakrishnan, 2018). The central theme of this system is the capability to defy the barriers of time and location, as it allows asynchronous teaching and learning where the teachers and student are no longer have to be physically present at the same place (Cavus, 2011). Since it was first introduced, various types of VLE have been developed to suit the miscellaneous educational settings, including higher institutions and schools. Among them, the most prominent are such as Blackboard, Moodle, Edmodo and Frog. Being adopted from the United Kingdom (UK), Frog VLE is the most recent LMS implemented in Malaysian schools under the 1BestariNet project (Nor-Azlah \& Fariza, 2014) with an allocation of RM1.475 Billion (MOE, 2014). It is hoped that over 10,000 public schools, 5 million students, 500,000 teachers, and 4.5 million parents will be connected together in the virtual learning community, and therefore, boost the quality of Malaysian education up to the highest level (Campbell, Harthi \& Karimi, 2015; MOE, 2014).

VLE including Frog is widely utilized in education (Veletsianos, Kimmons \& French, 2013; Balaam, 2013; Bennett, Wells \& Freelon, 2011; Conole \& Dyke, 2004; Hemmi, Bayne \& Land, 2009; Kali, Goodyear \& Markauskaite, 2011; Veletsianos, Kimmons \& French, 2013) which according to Trowler (2010) it has been an integral part of higher institutions and K-12 schools where most of the institutions have used this platform into their instructional activities. Various aspects as determinants for teachers to continue using VLE are policies of institutions (Bennett et al., 2011), beliefs and intention (Berggren, Burgos, Fontana, Hinkelman, Hung, Hursh \& Tielemans, 2005), and accessibility (Romeo, Lloyd \& Downes, 2012). Frog has been chosen by the Malaysian government because it is considered as most advanced learning platform compared to other platforms which facilitates educational institutions with the capability to provide a truly engaging environment (MOE, 2012a). Frog is more than a platform for instruction; Frog is an educational tool to achieve schools' long term plans of technology integration (1BestariNet, 2012).

In VLE implementation, studies informed that it is hard to encourage collaborative learning using VLEs (Conole \& Dyke, 2004), that teachers often do not utilize VLE to their full potential and only adapt or adopt a few set of VLE functionality (Hemmi et al., 2009; Veletsianos et al., 2013). In the context of areas, almost all developing countries faced similar hindrances in incorporating ICT including VLE into education. Poor infrastructure and facilities are two main hindrances (Rubagiza, Were \& Sutherland, 2011; Oyovwe-Tinuoye \& Adogbeji, 2013). Despite the large number of studies on VLE practices, tools, and success as well as hindrances, few studies have discussed teachers' level of intention to continue using VLE technology and factors influencing teachers' decision to keep using VLE into teaching and learning process. Therefore, this study was conducted in mix method design to get comprehensive data about teachers' level of intention and influencing factors on teachers' decision to keep using VLE into their teaching and learning process. 


\section{Methodology}

The current study is a mix method study using sequential explanatory design which has been carried out to describe the specific phenomenon under investigation. This kind of study is conducted based on the real situations without any element of interference or manipulation to the subjects or settings. The strategy in this study type is characterized by quantitative data collection and analysis in a first phase of the research, followed by the qualitative data (Brannen, 2005; Creswell 2014). We managed to organize the report of procedures into quantitative data collection and analysis followed by qualitative data procedures. This strategy emphasized how the qualitative findings helped elaborate the quantitative findings (Creswell, 2014).

\subsection{Quantitative}

A cross-sectional survey field study was employed, as the data has been collected at a single point in time. Field study refers to the non-experimental scientific inquiries designed to uncover the relationship between variables (Sekaran \& Bougie, 2009). Applying a survey field study provides a few advantages. Firstly, this research design could maximize the representative sampling of population units and therefore will improve the ability to generalize the findings (Scandura \& Williams, 2000). Secondly, the survey field research is usually high in accuracy, due to the instrument that is designed specifically to address the research questions (Slater, 1995). The instrument for survey research is usually in the form of a self-administered questionnaire, which will be completed by respondents (Sekaran \& Bougie, 2013). Thus, the structured questionnaire (see Table 1) which consists of a set of statements that were adapted from previous studies (DeLone \& McLean, 2003; Cheok \& Wong, 2016; Mardiana, Tjakraatmadja \& Aprianingsih, 2015; Raman \& Yamat, 2014; Wu, Hiltz \& Bieber, 2010) was used and reformulated to suit the perspective of the current study with Cronbach alpha .87 considered "good".

The population of this study are all K-12 teachers from the schools in the Northern Region of Peninsular Malaysia. The selection is based on the following justifications. First, the Northern Region with the immensity of 32, $404 \mathrm{~km} 2$ is the second largest region in the Peninsular Malaysia. Second, this region also being the largest school population with the total number of 2,347 or $32 \%$ of overall schools in Peninsular Malaysia (MOE, 2015a). In addition, it also has become the base for 97,503 teachers that serve in both rural and urban schools, scattered across the four states in the region (MOE, 2015b). Finally, another important aspect to consider in determining the location of study is the homogeneity of the sample. All the professional teachers in Malaysia are assumed as homogeneous in term of qualification and training (MOE, 2012a, 2012b). Therefore, the selection of Northern Region as a location for the study is sufficient to represent the whole population of the teachers nationwide (Kothari, 2004).

In the current study, the simple random sampling (probability sampling) has been used. However, due to the unavailability of the teachers' list, the randomizing procedure was conducted based on the list of the schools, as the sampling frame. The sampling process for this study involved three stages. At the first stage, the list of the K-12 schools (see Table 2) in the northern region is obtained from Educational Planning and Research Division (EPRD), MOE. Based on the predetermined sample size required for this study, 85 schools were selected. From each selected school, 10 teachers were chosen as respondents. This will total up to approximately 850 of sample size $\left(85^{* 10}=850\right)$. In the second stage, the random calculator, the 85 schools that will participate in the data collection process.

\begin{tabular}{|c|l|c|l|}
\hline \multicolumn{2}{|c|}{ Section } & Items (n) & \multicolumn{1}{c|}{ Sample of statement } \\
\hline 1. & Intention to continue using the Frog VLE. & 6 & I intend to continue using the Frog VLE. \\
\hline 2. & use the Frog VLE in the future. & 4 & I will regularly use the Frog VLE in the future. \\
\hline 3. & Access to Frog VLE. & 5 & $\begin{array}{l}\text { Assuming that I have access to the Frog VLE, I } \\
\text { intend to use it }\end{array}$ \\
\hline 4. & Frequent users of Frog VLE. & 5 & I intend to be a heavy user of Frog VLE \\
\hline
\end{tabular}

Table 1. The frequency and statement representative of the survey 


\begin{tabular}{|c|r|r|}
\hline State & Total No of Teachers & Respondents \\
\hline Perlis & 4,817 & 170 \\
\hline Kedah & 31,965 & 260 \\
\hline Penang & 20,395 & 180 \\
\hline Perak & 40,326 & 240 \\
\hline total & 97,503 & 850 \\
\hline
\end{tabular}

Table 2. Summary of Respondents for the Current Study

We have systematically developed the short instrument that meets the research objective. The instrument is divided into three sections; A, B and C. Section A aims to gather the demographic data of the respondents. Additionally, the last question in Section A represents a filtering question to determine whether the respondent has any experience using the Frog VLE system. For the respondent who answers 'None', he/she has to proceed to Section C, which consists of questions (reason for not using) related to the Frog VLE system. The other respondents will have to continue with Section B, which includes four section of questions regarding the intention to continue using the Frog VLE system among the teachers in Malaysia.

The current study achieved high level of response rate. During the two months of data collection via mail, 719 questionnaires were returned or about $84 \%$ response rate. After the data cleaning procedures, the usable data were 643 or about $75.6 \%$ of valid response rate which is far above the minimum response rate (Hair, Black, Babin \& Anderson, 2010). The IBM SPSS Statistics (SPSS) version 21 were employed for data analysis. For the questions in Section B, the measurement scale used is a seven-point Likert Scale, which ranges from 1 to 7 (' 1 ' extremely disagree to '7' extremely agree). This study applies the seven-point Likert Scale because it provides more widely spread scale values compared to five-point Likert Scale and thus reduces the possibility of respondent's bias, by just selecting a neutral value (Dwivedi, Papazafeiropoulou, Brinkman \& Lal, 2010). In fact, the seven-point Likert Scale has also been applied by many prominent researchers in the IS discipline (Agarwal \& Prasad, 1997; Armstrong, Brooks \& Riemenschneider, 2015; Bhattacherjee, 2001, Seddon \& Kiew, 1996; Venkatesh, Thong \& Xu, 2012).

\subsection{Qualitative}

We conducted interview sessions to obtain in-depth information after the analysis of the quantitative phase. When the survey instruments were distributed, we provided a column asking the respondents if they were willing to get involved in the interview. Surprisingly, there were fifty-three respondents agreed. Ten respondents were finally chosen to become the interview participants due to the demographic, financial and time factors. We hid participants' name, school, and other personal information the elaboration of the results to protect their right as human being (Mukminin, Rohayati, Putra, Habibi \& Aina, 2017; Creswell, 2014).

The interview was conducted between 60 to 80 minutes for each participant which questions was the established from survey results using Malay language (Creswell, 2014). We used a quite room recording the interview since we utilized Google docs voice typing which requires clear sound transcribing the data. By putting the sound in closed distant to computer, Google docs automatically typed the recording sound. We filed the transcription, printed it out, and marked them with colors examine the data. We coded and translated the transcription into English while putting the translated findings into themes in line with the survey result. To deal with the trustworthiness (Lincoln \& Guba, 1985; Mukminin \& McMahon, 2013), we listed verbatim examples of statements quoted from the transcribed interviews for the data presentation (Mukminin, Ali \& Ashari, 2015). We also conducted member checking and triangulation, comparing both the survey and interview data (Johnson \& Christensen, 2008; Creswell, 2014; Abrar, Mukminin, Habibi, Asyrafi, Makmur \& Marzulina, 2018). 


\section{Results}

The descriptive statistic was executed to analyze the demographic characteristic of the respondents. Regarding the gender, out of 643 respondents, 380 of them are female and 263 are male which equals to $59.1 \%$ and $40.9 \%$ respectively. The gender equation in Malaysian schools is reflected by this percentage that in almost schools, the female teachers are greater in number compared to male teachers. Even though the female percentage is higher, the ratio is considered as still valid for any statistical analysis, as there is no sample size assumptions for comparing two groups (Ross, 2017). Meanwhile, the average age of respondents was 39.85 years old (Mean: 39.85, Med: 39) with the minimum and maximum ages were 23 and 59 years old respectively (see Table 3 ).

In term of experience, majority of the respondents have more than 14 years of teaching experience $(\mathrm{n}=308,47.9 \%)$ followed 8 to 10 years $(\mathrm{n}=129,20.1 \%), 11$ to 13 years $(\mathrm{n}=91,14.2 \%), 5$ to 7 years $(\mathrm{n}=74,11.5 \%), 2$ to 4 years $(\mathrm{n}=39,6.1 \%)$ and finally less than a year $(\mathrm{n}=2,0.3 \%)$. Even though most of respondents are experienced teachers, they are still considered new to frog VLE, as this application has been introduced for less than seven years ago. As can be seen in the Table 2, the highest number of respondents have a year of frog VLE experience $(\mathrm{n}=187,29.1 \%)$, superseded by 3 years $(\mathrm{n}=153$, $23.8 \%), 2$ years $(\mathrm{n}=151,23.5 \%), 4$ years $(\mathrm{n}=78,12.1 \%), 5$ years $(\mathrm{n}=43,6.7 \%)$ and 6 years $(\mathrm{n}=31$, $4.8 \%)$.

The Table 4 summarizes the responses for each item of the questionnaire. To elaborate, the majority or $56 \%$ of respondents have moderate intention to continue using Frog VLE in the future, with the mean value of 4.14 . Similarly, $56 \%$ of respondents also declared that they will regularly use the system in the future. This percentage is at the moderate level, with the mean value of 4.20 . Meanwhile, $59.1 \%$ or 380 respondents insist that they will use the Frog VLE, whenever the access is available. Finally, majority of respondents (53\%) intend to be the moderate users with the mean value of 4.04 . Equally important to highlight is the percentage of low intention for three out of four items are greater than the high intention.

The analysis has uncovered that for item 1, 28.9\% of respondents have low intention while only $15.1 \%$ of them have high level of intention. Likewise, $27.2 \%$ and $33.1 \%$ of respondents rated the low intention for item 2 and 4 . On the contrary, only $16.8 \%$ and $13.8 \%$ of high intention respondents have been recorded for those similar items respectively. Nevertheless, the item 3 has demonstrates the bigger percentage for high intention $(21.8 \%)$ compared to low intention respondents $(19.1 \%)$, even though the different is comparatively small. To sum up, 397 of respondents declare that they have moderate overall intention to continue using Frog VLE in the future. This figure represents $61.7 \%$ of respondent, with the mean of 4.21 .

\begin{tabular}{|c|c|r|r|}
\hline Demographic Profile & Category & $\begin{array}{c}\text { Frequencies } \\
\text { (N=643) }\end{array}$ & $\begin{array}{c}\text { Percentage } \\
(\mathbf{\%})\end{array}$ \\
\hline Teaching Experience & $\leq 1$ Year & 2 & 0.3 \\
\hline & 2-4 Years & 39 & 6.1 \\
\hline & $5-7$ Years & 74 & 11.5 \\
\hline & $8-10$ Years & 129 & 20.1 \\
\hline & 11-13 Years & 91 & 14.2 \\
\hline & $\geq 14$ Years & 308 & 47.9 \\
\hline & $\leq$ 1 Year & 187 & 29.1 \\
\hline Frog VLE Experience & 2 Years & 151 & 23.5 \\
\hline & 3 Years & 153 & 23.8 \\
\hline & 4 Years & 78 & 12.1 \\
\hline & 5 Years & 43 & 6.7 \\
\hline & $\geq 6$ Years & 31 & 4.8 \\
\hline
\end{tabular}

Table 3. Analysis of Respondent's Demographic 


\begin{tabular}{|c|c|c|c|c|c|c|c|c|}
\hline \multirow{2}{*}{\multicolumn{2}{|c|}{ Section }} & \multicolumn{2}{|c|}{ Low } & \multicolumn{2}{|c|}{ Moderate } & \multicolumn{2}{|c|}{ High } & \multirow{3}{*}{$\begin{array}{r}\text { Mean } \\
4.14\end{array}$} \\
\hline & & \multirow{2}{*}{$\begin{array}{l}\mathbf{0} \\
28.9\end{array}$} & \multirow{2}{*}{$\begin{array}{l}\mathbf{n} \\
186\end{array}$} & \multirow{2}{*}{$\begin{array}{l}\% \\
56 \\
\end{array}$} & \multirow{2}{*}{$\begin{array}{l}\mathbf{n} \\
360\end{array}$} & \multirow{2}{*}{$\begin{array}{l}\text { \% } \\
15.1\end{array}$} & \multirow{2}{*}{$\begin{array}{l}\mathbf{n} \\
97\end{array}$} & \\
\hline 1. & Intention to continue using the Frog VLE. & & & & & & & \\
\hline 2. & use the Frog VLE in the future. & 27.2 & 175 & 56 & 360 & 16.8 & 108 & 4.20 \\
\hline 3. & Access to Frog VLE. & 19.1 & 123 & 59.1 & 380 & 21.8 & 140 & 4.48 \\
\hline 4. & Frequent users of Frog VLE. & 33.1 & 213 & 53 & 341 & 13.8 & 89 & 4.04 \\
\hline & Overall intention & 19.4 & 125 & 61.7 & 397 & 18.8 & 121 & 4.21 \\
\hline
\end{tabular}

Table 4. The Level of Intention to Continue Using VLE in the Future among Malaysian Teachers

From this analysis, it is noticeable that the vision of MOE to digitalize Malaysian education is yet to be achieved. As shown by the result of data analysis, there is a gap exists, in term of intention to use among the teachers as the VLE users. The analysis of item 2 has shown that the percentage of low intention teachers to become regular user is greater compared to high intention teachers, or $27.2 \%$ and $16.8 \%$ for each group. Similarly, the percentage of the teachers with the low intention of becoming the heavy user are higher $(33.1 \%)$ when compared to the high intention teachers $(13.8 \%)$. The result of these two items have demonstrated that current VLE implementation is still fail to meet the expectation of the Malaysian teachers, which caused the rejection toward the system.

Despite the moderate level of average intention to continuously use VLE, the low intention users are approximately higher in number compared to high intention users. Nevertheless, a close inspection to the item number 3 has unveiled that $21.8 \%$ of respondents are highly intent to use Frog VLE if the access is available. This percentage is higher than those who have low intention with the availability of access (19.1\%). This indicated that the accessibility is vital determinant for intention of VLE continuous usage among the teachers. Preferentially, the teachers will most probably use the VLE whenever the access is available. In light of this, the result of the study has depicted that the current infrastructures and facilities to support the VLE access are still inadequate, which would hinder the teachers from using system. In fact, without a proper access, there is no way the teachers can utilize the system, since VLE is internetbased environment, which requires synchronized and unsynchronized connections among the participants to support its features.

Hence, the further investigation on this aspect is critically needed. Moreover, several issues related to VLE accessibility need to be considered including digital gap between rural and urban schools, internet access in schools and other facilities such as the adequacy of PCs, supporting gadgets (smart phones, tablets, etc.) and supporting environments.

To investigate outcomes of teachers' responses, interviews were sorted according to textual content into distinct categories. These categories broadly divided into four groups a) Teachers Workload b) Accessibility c) Acceptance and d) Competency. The question "Why you don't used FROG VLE?" answered only 51 teachers (Male 17.6\% Female 82.4\%) as shown as Table 5.

Findings show that Accessibility is the highest percentage (39.2\%), followed by Competency $(29.4 \%)$, Teachers Workload (17.6\%) and Acceptance (13.7\%) as shown in Table 6.

As we finished with the analysis of quantitative data, we started to conduct the interview with the ten teachers which the procedures have been elaborated in the previous section. The participants in this interview were seven females (Farrah; Malika; Noor; Palma; Rita; Tania; Siti) and three males (Azka; Khan; Zohri). Their names were masked in this data elaboration.

Being asked about hindering factors of the intention to continue using VLE in their teaching activities, various responses were given by the participants. However, most teachers agreed that accessibility and teachers' competency were the main issues. Acceptance and workload were also informed as the factors in line with the continuations of VLE use. 


\begin{tabular}{|c|r|r|}
\hline \multicolumn{3}{|c|}{ Open Ended Survey } \\
\hline Sex & Frequency & \multicolumn{1}{c|}{ Percentage } \\
\hline Female & 42 & $82.4 \%$ \\
\hline Male & 9 & $17.6 \%$ \\
\hline Total & 51 & $100 \%$ \\
\hline
\end{tabular}

Table 5. Open ended survey information

\begin{tabular}{|c|r|}
\hline Categories & Frequency/Percentage \\
\hline Teachers Workload & $9(17.6 \%)$ \\
\hline Accessibility & $20(39.2 \%)$ \\
\hline Competency & $15(29.4 \%)$ \\
\hline Acceptance & $7(13.7 \%)$ \\
\hline Total & $100 \%$ \\
\hline
\end{tabular}

Table 6. Categories

Lack of accessibility emerged from the interview when all participants, especially whose schools were considered to be located in the suburb or far away from the city centre informed that internet access did matter in the frog VLE integration. Two teachers said,

"Teaching in the school where internet and other supporting tools are not really facilitating is hard. I am not saying that the tools are not available; my schools have the technological equipment but they frequently do not work," (Farrah)

"It is difficult to use VLE here. The access is the main problem and I will keep using VLE once this problem is solved." (Azka)

Not only revealed by the participants from suburb schools, the information about accessibility factor in VLE use continuation was also informed by those who teach in schools located in or near major cities namely Penang, Perlis and Kedah. We asked Rita from Perlis and Tania from Kedah about what is wrong with the accessibility in the schools where they teach that are located in the city centre and they said with almost similar statements that the tools sometimes do not work properly even though they taught in the city schools where technology is supposedly not a big issue. As a result, the situation makes them to discontinue integrating VLE into their teaching activities in some certain situations. Another participant teaching in Penang informed,

"I am not saying that we stop using frog VLE but I seldom use that in our teaching and learning activity. The access sometimes makes it hard to use VLE in the classroom. I planned using the frog in my lesson plan; however, it sometimes does not run smoothly when unpredictable situations emerged like the media do not function." (Noor)

In addition to accessibility factor, teachers' competence in VLE integration is also informed by most participants as a factor hindering the VLE use continuation, especially those who have lack experience in using technology who are mostly senior teachers. Rita, 48 years old, commented that she was trying hard to learn the VLE but she felt that it was hard for her to understand and used the technology because she had many jobs to do in relation to teaching and many administrative tasks assigned by the authority. The other participant, Palma (56) informed,

"I am really having difficulties with this Virtual Learning. There are many features that I do not understand. As a senior teacher, I realize my weakness but I have to follow the trends since all students are now digital natives; however, I have to say I don't agree with that, traditional teaching is better." (Palma)

From the perspective of new teachers who are accustomed with the use of technology, the competence is not a main issue. However, they concerned about their seniors of the VLE use and frequently help them 
explain and operate the media. Zohri (37) informed that he always offered help for senior teachers using VLE felt happy about it, helping them. He continued,

"There are sometimes they [senior teachers] looked confused using sorts of technology and I understand the situation. By helping them, I also obtained social benefits like they also shared their practical experience in teaching." (Zohri)

Beside technology accessibility and teachers' competence, teachers' acceptance and teaching workload were also informed to be factors in VLE integration continuation. The acceptance of technology is revealed as a factor determining, boosting, or decreasing the technology integration in the classroom by six interview participants. They stated that technology integration in the teaching and learning process is not really important compare to the content or pedagogical experience. Palma stated in the interview that she did not fully agree that the use of technology including frog VLE will improve the quality of teaching. She therefore preferred to use traditional method in her teaching.

The last factor, teachers' workload was also discussed by more than five participants in the interview. They argued that they had so many jobs to do related to teaching; planning teaching, doing teaching, and conducting teaching and learning assessment. In addition, they also had to deal with some administrative thing such as writing report to the authorities on what they have done in the process of teaching and learning. One of the interview participant said,

"Nowadays, teaching is an activity without ending. We must teach and plan the teaching as well as giving our time doing assessment or evolution. Besides, we have to do some administrative obligation that is not related to teaching. What a very hectic time we have as teachers." (Siti)

\section{Discussion}

The level of success for ICT integration in education differs in each country around the world. Certain countries (especially developed countries, for example, Finland and the United States) have proved that ICT is effective in teaching and learning while at the same time been implemented regularly by teachers (Aristovnik, 2012). On the contrary, other countries (especially developing countries like Malaysia, Nigeria, and Bangladesh) are still in the beginning stage of ICT integration, without any clear positive sign of revenue for the investment. Nevertheless, the integration of ICT into education also triggers controversial debate among scholars, respectively in both disciplines, ICT and education (Ghavifekr, Razak, Ghani, Ran, Meixi \& Tengyue, 2014; Prasojo et al., 2017). In facts, the existing literature from the past 30 years has provided plentiful numbers of research conducted regarding the issues (Underwood \& Dillon, 2011). Yet, the consensus of the ICT impact toward education remains unclear (Aristovnik, 2012).

From the quantitative data, the intention to continue using VLE among the Malaysian teachers is at the moderate level, with the overall mean value of 4.21. The factors that has been identified through qualitative study is teachers' workload, accessibility, competency and acceptance. Although the mean value of teachers' willingness to use VLE with the existence of access is 4.48 (moderate), the percentage of high intention teachers is higher compared to low intention teachers, with the values of $21.8 \%$ and $19.1 \%$ respectively. This phenomenon signifies that the teachers will use the VLE if the proper access to the system is provided. Accessibility is the highest percentage according to the qualitative study. This finding is supported by the DeLone and McLean IS Success Model, which suggested that the accessibility as one of the measurement for System Quality will have significant influence toward the Intention to Use (DeLone \& McLean, 2003). Apparently, the finding of the current study has provided the useful insight regarding the current scenario of VLE implementation in Malaysia, which should call the attention of VLE stakeholders in Malaysia for future improvement. More importantly, the finding of this study will also provide a basis for future researcher to investigate the factors that will affect the usage the VLE success among the Malaysian teachers. Nonetheless, DeLone and McLean (2003) stressed that the successful implementation of any Information Systems, including VLE relies on several other dimensions that are inter-related to each other. Therefore, the future research should also focus on this aspect by investigating 
VLE success among the Malaysian teachers. The findings should be the red alert for VLE researchers, as it signifies that the current implementation of VLE is not in the right track of success. Moreover, the circumstance if left untreated, could probably lead to total abandonment of the system. However, so far there are lack of studies that investigate the issue continuous usage of VLE, especially among the teachers. Therefore, this study was conducted to fill the gap by thoroughly examine the current state of intention to continuously use VLE technology among the Malaysian teachers.

\section{Declaration of Conflicting Interests}

We declared no potential conflicts of interest with respect to the research, authorship, and/or publication of this article.

\section{Funding}

We received no financial support for the research, authorship, and/or publication of this article.

\section{References}

BestariNet. (2012). 1BestariNet - Kementerian pendidikan Malaysia: Soalan lazim. Available at: http://1bestarinet.net/?page id=21 (Accessed: September, 2016).

Abdelhag, M.E., \& Osman, S.E.F. (2014). SOA for effective data integration of virtual learning environment systems. International Journal of Advanced Research in Computer Science and Software Engineering, $4(6), 680-685$.

Abrar, M., Mukminin, A., Habibi, A., Asyrafi, F., Makmur, M., \& Marzulina, L. (2018). If our English isn't a language, what is it? Indonesian EFL student teachers' challenges speaking English. The Qualitative Report, 23(1), 129-145.

Agarwal, R., \& Prasad, J. (1997). The role of innovation characteristics and perceived voluntariness in the acceptance of information technologies. Decision Sciences, 28(3), 557-582.

https://doi.org/10.1111/j.1540-5915.1997.tb01322.x

Aristovnik, A. (2012). The impact of ICT on educational performance and its efficiency in selected eu and oecd countries: a non-Parametric Analysis. Turkish Online Journal of Educational Technology, 11(3), 144-152.

Armstrong, D.J., Brooks, N.G., \& Riemenschneider, C.K. (2015). exhaustion from information system career experience: Implication for turn-away intention. MIS Quarterly, 39(3), 713-727.

Balaam, M. (2013). A response from M. Balaam. Computers \& Education, 69, 517-519. ISSN: 0360-1315. https://doi.org/10.1016/j.compedu.2013.04.009

Barker, J., \& Gossman, P. (2013). Te learning impact of a virtual learning environment: Students' views. Teacher Education Advancement Network Journal, 5(2),19-38.

Bennett, W.L., Wells, C., \& Freelon, D. (2011). Communicating civic engagement: Contrasting models of citizenship in the youth web sphere. Journal of Communication, 61(5), 835-856.

https://doi.org/10.1111/j.1460-2466.2011.01588.x

Berggren, A., Burgos, D., Fontana, J., Hinkelman, D., Hung, V., Hursh, A., \& Tielemans, G. (2005). Practical and Pedagogical Issues for Teacher Adoption of IMS Learning Design Standards in Moodle LMS. Journal of Interactive Media in Education, 2(02), 2. https://doi.org/10.5334/2005-2

Bhattacherjee, A. (2001). Understanding information systems continuance: An expectation-confirmation Model. MIS Quarterly, 25(3), 351-370. https://doi.org/10.2307/3250921 
Bhuasiri, W., Xaymoungkhoun, O., Zo, H., Rho, J.J., \& Ciganek, A.P. (2012). Critical success factors for e-learning in developing countries: A comparative analysis between ICT experts and faculty. Computers \& Education, 58(2), 843-855.

Brannen, J. (2005). Mix-method research: Discussion paper. NCRM research review paper.

Britain, S., \& Liber, O. (2004). A framework, for the pedagogical evaluation of eLearning environments. Available at: https://hal.archives-ouvertes.fr/hal-00696234

Campbell, C., Harthi, A. Al, \& Karimi, A. (2015). Evaluation of the learning designs of cloud-based content using the tpack framework. In EdMedia. Quebec: ResearchGate.

Cavus, N. (2011). Selecting a learning management system (LMS) in developing countries: Instructors' evaluation. Interactive Learning Environments, 21(5), 1-19. https://doi.org/10.1080/10494820.2011.584321

Cheok, M.L., \& Wong, S.L. (2016). Frog virtual learning environment for malaysian schools: Exploring teachers' experience. In Zhang, J., Yang, J., Chang, M., \& Chang, T. (Eds.), ICT in Education in Global Context (201-209). Singapore: Springer Science+Business Media. https://doi.org/10.1007/978-981-10-0373-8_10

Conole, G., \& Dyke, M. (2004). Understanding and using technological affordances: A response to Boyle and Cook. ALT-J, 12(3), 301-308. https://doi.org/10.3402/rlt.v12i3.11261

Creswell, J.W. (2014). Research design: qualitative, quantitative, and mixed methods approaches. Thousand Oaks, CA: Sage.

DeLone, W.H., \& McLean, E.R. (2003). The DeLone and McLean model of information systems success: A ten-year update. Journal of Management Information Systems, 19(4), 9-30. https://doi.org/10.1073/pnas.0914199107

Dimelis, S.P., \& Papaioannou, S.K. (2010). FDI and ICT effects on productivity growth: A comparative analysis of developing and developed countries. The European Journal of Development Research, 22(1), 79-96.

Dwivedi, Y.K., Papazafeiropoulou, A., Brinkman, W.P., \& Lal, B. (2010). Examining the influence of service quality and secondary influence on the behavioural intention to change internet service provider. Information Systems Frontiers, 12(2), 207-217. https://doi.org/10.1007/s10796-008-9074-7

Eom, S.B., Ashill, N.J., Arbaugh, J.B., \& Stapleton, J.L. (2012). The role of information technology in e-learning systems success. Human Systems Management, 31(3-4), 147-163.

https://doi.org/10.3233/HSM-2012-0767.

Ghavifekr, S., Razak, A.Z.A., Ghani, M.F.A., Ran, N.Y., Meixi, Y., \& Tengyue, Z. (2014). ICT Integration in Education: Incorporation for Teaching \& Learning Improvement. Malaysian Online Journal of Educational Technology, 2(2), 24-45.

Goldin, C., \& Katz, L. F. (2018). The race between education and technology. In Inequality in the 21st Century (49-54). Routledge.

Habibi, A., Mukminin, A., Riyanto, Y., Prasojo, L.D., Sulistiyo, U., Sofwan, M. et al. (2018). Building an online community: Student teachers' perceptions on the advantages of using social networking services in a teacher education program. Turkish Online Journal of Distance Education, 19(1), 46-61.

Hair, J.F., Black, W.C., Babin, B.J., \& Anderson, R.E. (2010). Multivariate data analysis (7th ed.). Pearson Prentice Hall.

Halonen, R., Thomander, H., \& Laukkanen, E. (2010). DeLone \& McLean IS success model in evaluating knowledge transfer in a virtual learning environment. International Journal of Information Systems and Social Change, 1(2), 36-48. https://doi.org/10.4018/jissc.2010040103 
Hemmi, A., Bayne, S., \& Land, R. (2009). The appropriation and repurposing of social technologies in higher education. Journal of Computer Assisted Learning, 25(1), 19-30. https://doi.org/10.1111/j.13652729.2008.00306.x

Hu, X., Gong, Y., Lai, C., \& Leung, F.K. (2018). The relationship between ICT and student literacy in mathematics, reading, and science across 44 countries: A multilevel analysis. Computers \& Education, 125, $1-13$.

Johnson, R.B., \& Christensen, L.B. (2008). Educational research: Quantitative, qualitative, and mixed approaches (3rd ed.). Thousand Oaks, CA: Sage

Kali, Y., Goodyear, P., \& Markauskaite, L. (2011). Researching design practices and design cognition: Contexts, experiences and pedagogical knowledge-in-pieces. Learning, Media and Technology, 36(2), 129-149. https://doi.org/10.1080/17439884.2011.553621

Karunaratne, T., Peiris, C., \& Hansson, H. (2018). Implementing small scale ICT projects in developing countries-how challenging is it?. International Journal of Education and Development using ICT, 14(1).

Kothari, C.R. (2004). Research methodology: methods and techniques (2nd ed.). New Delhi, India: New Age International (P) Limited.

Kozma, R.B., \& Vota, W.S. (2014). ICT in developing countries: Policies, implementation, and impact. In Handbook of research on educational communications and technology (885-894). New York, NY: Springer.

Lincoln, Y.S., \& Guba, E.G. (1985). Naturalistic inquiry. Sage.

Lubin, I.A., \& Lubin, I.A. (2018). ICT-Supported Innovations in Small Countries and Developing Regions. Springer.

Mardiana, S., Tjakraatmadja, J.H., \& Aprianingsih, A. (2015). DeLone-McLean information system success model revisited: The separation of intention to use-use and the integration of technology acceptance models. International Journal of Economics and Financial Issues, 5(1S), 172-182.

MOE (2006). Pelan induk pembangunan pendidikan 2006-2010 (Education development blue print plan 2006-2010). Perpustakaan Negara Malaysia. Putrajaya. Ministry of Education, Malaysia.

MOE (2012a). Laporan awal pelan pembangunan pendidikan Malaysia 2013-2025 (Preliminary report on Malaysia's education development plan 2013-2025). Kementerian Pelajaran Malaysia. Putrajaya. Ministry of Education, Malaysia.

MOE (2012b). Pra perkhidmatan (Pre Service). Available at: http://www.moe.gov.my/my/praperkhidmatan (Accessed: August, 2016). Ministry of Education, Malaysia.

MOE (2014). Perkbidmatan 1Bestarinet (Service 1Bestarinet). Putrajaya, Malaysia. Ministry of Education, Malaysia. Available at: https://egov.nik.gov.pl/g/egov/MY/2014/BestariNnet/1BESTARINET\%20FOR \%20EUROSAI\%20CUBE.pdf.

MOE (2015a). Bilangan sekolah mengikut jenis dan negeri (Number of schools by type and state). Ministry of Education, Malaysia. Available at: http://www.moe.gov.my/my/statistik-sekolah (Accessed: January, 2016).

MOE (2015b). Perangkaan pendidikan Malaysia 2015 (Malaysian education statistics 2015). Putrajaya: Bahagian Perancangan dan Penyelidikan Dasar Pendidikan. Ministry of Education, Malaysia.

MOF (2014). Maklum balas ke atas laporan ketua audit negara 2013 Siri 3 (Feedback Audit Report 2013 Series 3). Putrajaya, Malaysia. Ministry of Finance, Malaysia.

Mosquera, L.H. (2017). Impact of implementing a Virtual Learning Environment (VLE) in the EFL classroom. Íkala, Revista de Lenguaje y Cultura, 22(3), 479-498. https://doi.org/10.17533/udea.ikala.v22n03a07

Mueller, D., \& Strohmeier, S. (2011). design characteristics of virtual learning environments: state of research. Computers \& Education, 57(4), 2505-2516. https://doi.org/10.1016/j.compedu.2011.06.017 
Mukminin, A., Ali, R.M., \& Ashari, M.J.F. (2015). Voices from within: Student teachers' experiences in english academic writing socialization at one Indonesian teacher training program. The Qualitative Report, 20(9), 1394-1407.

Mukminin, A., \& McMahon, B.J. (2013). International graduate students' cross-cultural academic engagement: Stories of Indonesian doctoral students on an American campus. Qualitative Report, 18, 69.

Mukminin, A., Rohayati, T., Putra, H.A., Habibi, A., \& Aina, M. (2017). The long walk to quality teacher education in Indonesia: Student teachers' motives to become a teacher and policy implications. Illkögretim Online, 16(1).

Niebel, T. (2018). ICT and economic growth-Comparing developing, emerging and developed countries. World Development, 104, 197-211.

Nor-Azlah, M.J., \& Fariza, K. (2014). Keberkesanan kemahiran komunikasi di kalangan guru dalam penggunaan persekitaran pembelajaran maya (Frog VLE). Dlm. Aliran Terkini Dalam Pengajaran Sumber \& Teknologi Maklumat: Impaknya ke atas Penyelidikan dalam Pendidikan, disunting oleh Fariza Khalid, Md Yusoff Daud \& Mohd Jasmy Abd Rahman (64-68). Bangi: Penerbit Fakulti Pendidikan, UKM.

Nor-Fadzleen, S., \& Halina, M.D. (2013). Knowledge management enhancement in virtual learning environment (VLE) in Malaysian schools. Paper presented at International Conference on Virtual Learning Environment (ICVLE). Malaysia: Ministry of Education.

Owen, S., Palekahelu, D., Sumakul, T., Sekiyono, E., \& White, G. (2017). Systematic educational change and teacher skill-building in developed and developing countries: the importance of teacher peer learning groups. Teacher Development, 1-17.

Oyovwe-Tinuoye, G., \& Adogbeji, B.O. (2013). Information communication technologies (ICT) as an enhancing tool in quality education for transformation of individual and the nation. International Journal of Academic Research in Bussines and Social Sciences, 3(4), 21-33.

Peeraer, J., \& Van-Petegem, P. (2011). ICT in teacher education in an emerging developing country: Vietnam's baseline situation at the start of "the year of ICT." Computers and Education, 56(4), 974-982. https://doi.org/10.1016/j.compedu.2010.11.015

Prasojo, L.D., Habibi, A., Mukminin, A., Muhaimin, Ikhsan, Taridi, M. et al. (2017). Managing digital learning environments: Student teachers' perception on the social networking services use in writing courses in teacher Education. The Turkish Online Journal of Educational Technology, 16(4), 42-55.

Raman, A., \& Rathakrishnan, M. (2018). Frog VLE: Teachers' technology acceptance using UTAUT model. International Journal of Mechanical Engineering and Technology (IJMET), 9(3), 529-538.

Raman, K., \& Yamat, H. (2014). Barriers teachers face in integrating ICT during English lessons: A case study. The Malaysian Online Journal of Educational Technology, 2(3), 11-19.

Romeo, G., Lloyd, M., \& Downes, T. (2012). Teaching Teachers for the Future (TTF): Building the ICT in education capacity of the next generation of teachers in Australia. Australasian Journal of Educational Technology, 28(6), 949-964. https://doi.org/10.14742/ajet.804

Ross, S.M. (2017). Introductory statistics. Academic Press. https://doi.org/10.1016/B978-0-12-804317-2.00031-X

Rubagiza, J., Were, E., \& Sutherland, R. (2011). Introducing ICT into schools in Rwanda: Educational challenges and opportunities. International Journal of Educational Development, 31(1), 37-43. https://doi.org/10.1016/j.ijedudev.2010.06.004

Scandura, T.A., \& Williams, E.A. (2000). Research methodology in management: Current practices, trends, and implications for future research. The Academy of Management Journal, 43(6), 1248-1264. 
Seddon, P.B., \& Kiew, M.-Y. (1996). A partial test and development of Delone and Mclean's model of IS success. Australasian Journal of Information Systems, 4(1), 90-109. https://doi.org/10.3127/ajis.v4i1.379

Sekaran, U., \& Bougie, R. (2009). Research methods for business: A skill building approach (5th ed.). West Sussex, England: Wiley.

Sekaran, U., \& Bougie, R. (2013). Research methods for business: A skill-building approach (6th ed.). West Sussex, England: Wiley.

Slater, S.F. (1995). Issues in conducting marketing strategy research. Journal of Strategic Marketing, 3, 257-270. https://doi.org/10.1080/09652549500000016

Sneha, J.M., \& Nagaraja, G.S. (2013). Virtual learning environments: a survey. International Journal of Computer Trends and Technology (IJCTT), 4(6), 1705-1709.

Trowler, V. (2010). Student engagement literature review. The Higher Education Academy, 11(1), 1-15.

Underwood, J., \& Dillon, G. (2011). Chasing dreams and recognising realities: Teachers' responses to ICT. Technology, Pedagogy and Education, 20(3), 317-330. https://doi.org/10.1080/1475939X.2011.610932

Uzunboylu, H., Bicen, H., \& Cavus, N. (2011). The Efficient virtual learning environment: A case study of web 2.0 tools and windows live spaces. Computers and Education, 56(3), 720-726. http://doi.org/10.1016/j.compedu.2010.10.014

Vanderlinde, R., Aesaert, K., \& Van-Braak, J. (2014). Institutionalised ICT use in primary education: A multilevel analysis. Computers and Education, 72, 1-10. https://doi.org/10.1016/j.compedu.2013.10.007

Veletsianos, G., Kimmons, R., \& French, K.D. (2013). Instructor experiences with a social networking site in a higher education setting: Expectations, frustrations, appropriation, and compartmentalization. Educational Technology Research and Development, 61(2), 255-278. https://doi.org/10.1007/s11423-012-9284-z

Venkatesh, V., Thong, J.Y.L., \& Xu, X. (2012). Consumer acceptance and use of information technology: extending the unified theory of acceptance and use of technology. MIS Quarterly, 36(1), 157-178.

Wilson, B.G. (1996). Constructivist Learning Environments: Case Studies in Instructional Design. Educational Technology Research and Development, 44(3), 99-101.

Wirawani, K., \& Rosnani, H. (2013). Pelan pembangunan pendidikan malaysia 2013-2025: Unity among students. Social Science Research Network, 27(1), 1-12. https://doi.org/10.1016/j.tate.2010.08.007

Wu, D., Hiltz, S.R., \& Bieber, M. (2010). Acceptance of educational technology: Field studies of asynchronous participatory examinations. Communications of the Association for Information Systems, 26(1), 21.

Xchanging. (2014). Case study: ministry of education, Malaysia. Xchanging Group. Kuala Lumpur. Available at: https://www.xchanging.com/sites/default/files/XCH_CaseStudy_1BestariNet_May2014_0\%20UPDATED.pdf

Zhou, T. (2013). An empirical examination of continuance intention of mobile payment services. Decision Support Systems, 54(2), 1085-1091. https://doi.org/10.1016/j.dss.2012.10.034

Published by OmniaScience (www.omniascience.com)

Journal of Technology and Science Education, 2018 (www.jotse.org)

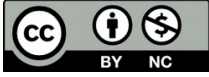

Article's contents are provided on an Attribution-Non Commercial 4.0 Creative commons International License. Readers are allowed to copy, distribute and communicate article's contents, provided the author's and JOTSE journal's names are included. It must not be used for commercial purposes. To see the complete licence contents, please visit https://creativecommons.org/licenses/by-nc/4.0/. 